\title{
DEVELOPING SMART, AFFORDABLE AND SUSTAINABLE MULTI-RESIDENT HOUSING THROUGH SOLAR ENERGY AND ELECTRIC TRANSPORT INTEGRATION
}

\author{
NEIL W. THOMPSON \\ Queensland University of Technology, Australia
}

\begin{abstract}
The purpose of this paper is to investigate the economic, environmental and social benefits afforded to the development of smart, affordable and sustainable multi-resident housing through the integration of solar energy and electric transport systems. A new integrated sustainable design (ISD) model was first developed from a literature review and case study followed by a survey study of multi-resident housing developments to inform synthesis of a Commuter Energy and Building Utilities System (CEBUS) decision support tool (DST) for subsequent validation at a pilot site. Application of integrated solar energy and electric transport systems in multi-resident housing developments demonstrated significant potential annual savings on average household income together with drastic reductions in household greenhouse gas $(\mathrm{GHG})$ emissions from electricity consumption and transport usage. Significant social benefits were also identified through the potential reduction of mortgage stress and road rage incidents. This research for the first time quantifies the electricity and transport cost benefits offered by the proposition that buildings and transportation vehicles can provide an integrated and interactive renewable power source with generation between and for each other so as to help drive the development of smart, affordable and sustainable multi-resident housing stock.
\end{abstract}

Keywords: integration, solar energy, electric transport, smart, affordable, sustainable, multi-resident housing, greenhouse gas emissions.

\section{INTRODUCTION}

Housing affordability is a worldwide concern. For example, recent research in the UK by Mulliner and Maliene [1] has highlighted rising housing prices as a result of government intervention in financial markets that was originally designed to assist ongoing growth in the economy. Research in the US by Pollack et al. [2], has also demonstrated a link between declining public health and increasing problems with housing affordability whilst housing costs in Brazil have continued to increase despite over twenty percent of inner city land area in Sao Paulo remaining vacant (Sperandelli et al. [3]). Currently, high prices in housing markets around the world are set against a backdrop of continuing efforts in the development of smart, affordable and sustainable housing through innovative designs, materials and systems. "Eco" homes aim to balance the issues of climate change, resource use and quality of life (Prickett and Bicknell [4]). Adaptive re-use of existing buildings is being promoted as a means of reducing the use of new materials in sustainable housing developments (Yung et al. [5]). However, few of these sustainable homes are available at or below target affordability price points as determined by the Housing Industry Association (HIA) [6]. There has been extensive advocating for sustainable housing guidelines and planning schemes by governments, professional associations and whereby rail stations are located within pedestrian walking distance from new housing developments (Zhao and Deng [7]) together with greater use of higher density multi-resident housing developments, which have reduced per capita energy consumption and greenhouse gas (GHG) emissions (Norman et al. [8]). However, to date, the building industry has failed to deliver sufficient stock of smart and sustainable yet affordable housing as evidenced by the emergence of non-government 
housing organisations such as "Habitat for Humanity", who are actively working to provide clean, affordable and sustainable housing for the estimated 100 million homeless people around the world (Habitat [9].) At the same time, utilisation of public transport has actually declined in many countries, including Canada, the USA and Australia, to under $10 \%$ of the population. This has resulted in sharp increases in traffic congestion, GHG emissions and household transport costs when compared with 1990 levels (Gipton [10]). Increased investment in toll-ways and tunnels has actually increased car usage as a result of improved average trip speeds thus further contributing to the decline in public transport patronage around the world (Chen and Wen[11]).

This issue of affordability is seen as a major barrier to increased uptake of smart and sustainable housing construction. Many assume smart and sustainable housing is more expensive to execute when compared to standard practices and that more sustainable options are therefore not financially viable (Pitt et al. [12]). At the same time, the perception that smart and sustainable transportation methods act to restrict personal mobility is another major barrier to be overcome before we see an increased uptake of genuine sustainable housing construction that incorporates sustainable transport methods (Delucchi and Kurani [13]). Accordingly, the property industry worldwide is seeking new development guidelines and frameworks that can integrate affordability considerations with sustainability measures. The industry also needs decision support tools that can help turn the conflicting demands of affordability, reduced environmental impact and improved mobility into saleable housing stock for the mainstream market. This paper presents the results of a research project aimed at identifying potential savings in up-front construction cost and ongoing utilities and transport costs available through the integrated application of best practice in sustainable construction and TOD strategies in order to develop smart, affordable and sustainable multiresident housing.

\section{DEVELOPMENT OF A NEW INTEGRATED}

\section{SUSTAINABLE DESIGN MODEL}

A detailed literature review and case studies were first undertaken of those methods that have proven to provide both first capital and ongoing operating cost expense reductions in order to inform the development of a new integrated sustainable design (ISD) model to help deliver smart, affordable and sustainable multi-resident housing. Smart, affordable and sustainable multi-resident housing design uses a wide range of passive and active design principles and practices to simultaneously improve environmental, social and economic aspects.

For example, significant life cycle operating cost benefits can be achieved through strong passive building design (Chaturvedi [14]). Research by Miller [15] into the impact of best practice passive building design using cross-ventilation has shown a reduction in energy usage of $50 \%$ when compared with standard per capita energy usage. Development of district scale "microclimates" has also contributed to improved urban comfort without the need for active cooling systems (Triantis et al. [16]). "Green urbanism" is another sustainable design concept that has been developed to combat rapid urban growth through the move towards closed-loop, rather than linear, utilities infrastructure metabolisms for housing estates (Codoban and Kennedy [17]). Examples such as integrated rainwater harvesting and stormwater management systems have provided capital cost savings of up to $50 \%$ and ongoing potable water operating cost reductions of up to $75 \%$ (Reidy [18]).

Additional first capital and life cycle cost benefits are possible through the use of virtual design technologies. These allow housing designers to develop and test building solutions with confidence in building constructability and long-term operational performance (Bailey and Brodkin [19]). Information and Communication Technology (ICT) has improved construction industry productivity, bridged gaps in communication between stakeholders and 
encouraged the implementation of new processes resulting in reductions of up to $25 \%$ in design time (Issa et al. [20]). Furthermore, use of ICT has enabled planners to assess the social and environmental impacts of various sustainable design options at the regional level in order to help define protected areas between cities (Wang et al. [21]). This Building Information Modelling (BIM) process allows project teams to quickly and accurately assess green building credentials for various material, equipment and systems selections (Barnes [22]). Having started with 3D modelling for spatial and technical co-ordination, this BIM process now extends to 8D "joined-up thinking" across time, cost, procurement and operations parameters so as to ensure a higher level of design efficiency in order to reduce overall construction time and rework cost (Forsspac [23]). Additional initial construction cost reductions are offered through linking BIM techniques to housing prefabrication. This involves constructing housing structures and key sub-components in a controlled factory environment before transferring them to their final destination for assembly. The benefits of off-site manufacturing (OSM) include a reduction in embodied energy and material waste, together with reduced construction costs of up to $12 \%$, through improved constructability and reduced costs for major sub-components such as heating, ventilation and air-conditioning (HVAC) systems (Meiling et al. [24]).

Incorporating sustainable design principles into new homes and housing estates can also attract new economic models to help reduce first capital and ongoing debt servicing costs. Density bonuses are changes to a higher unit yield, whilst tax breaks/credits and/or direct financial grants can be provided to developers in return for achievement of a minimum specification sustainability rating. Research into factors that have led to an increase in sustainable housing development in the US has shown that these economic incentives are the main determinants for government regulators to consider when trying to encourage more affordable and sustainable housing development (Sauer [25]). Increased use of distributed utility systems in accordance with "green urbanism" principles, such as combined rainwater harvesting and stormwater management systems, has also provided opportunities for deployment of the Design, Build, Operate and Maintain (DBOM) method of project delivery and financing. A single contract is awarded for the design, construction, operation and maintenance of discrete items of utility plant in return for a defined user-pays fee over a fixed period (Dahl et al. [26]). Multi-resident developments have also demonstrated the ability of the body corporate to establish a "user pays" system based on DBOM contracts to recover the cost of capital equipment over its economic service life, rather than having the entire cost of the equipment paid for up-front by the developer/first home owner. This mechanism has been used by developers to remove capital equipment purchase costs from the home's selling price for items such as hot water systems, air-conditioning, water treatment systems, electrical switchboards and utility meters (Warnken [27]). The resultant reduction of up-front land and utilities and transport infrastructure cost per house provided by these financial incentives and DBOM contracts can be combined with the preceding sustainable design principles to provide further reduction in initial construction cost and ongoing operating costs.

Best practice sustainable de/construction methods using locally recycled building materials for integration with new renewable building materials during the construction process together with re-use of de/construction materials recovered from the work site and/or expired DBOM contracts in accordance with world class zero waste protocols have also shown to reduce build costs by up to $10 \%$ and reduce environmental impact on the host community through decreased transport of new construction materials to the work site (Kuhlen [28]). For example, large numbers of used electric vehicle (EV) batteries are now entering the market via expired DBOM contracts hence they are being re-packaged and used 
in new construction projects as part of a combined solar power / battery storage and electrical demand management system (Casey [29]).

One of the key life cycle cost benefits observed in multi-resident housing developments is the ability of the body corporate to purchase and on-supply services to both the common areas of the community and individual residents. These services have ranged from provision of utilities such as electricity, gas, water and broadband communications through to maintenance of the grounds or provision of a community recreation centre. By aggregating demand for these services across the entire community, savings of at least $20 \%$ have been achieved when compared with direct provision of the same services to individual residents and owners in common (Tucker [30]). Use of advanced modelling tools designed to deal with the uncertainty of community scale utilities systems has also enabled a reduction in up-front capital costs for utilities infrastructure which has translated to lower capital cost per house (Lin et al. [31]). This demand aggregation model has also provided transport services via community owned boats in coastal developments and community owned shuttle vehicles at multi-resident resorts, industrial parks and retirement villages. The resident manager or volunteer driver assists residents, guests and staff with airport transfers and connection with public transport nodes. This concept of community carpooling and/or sharing has successfully demonstrated a reduction in private vehicle ownership costs for residents at The Waterfront [32] multi-resident development in Sydney, Australia where the local council has provided the developer with a reduction of seven (7) car parking bays for each pool/share car. The resultant reduction in personal utilities and transport costs offered through utilities and transport demand aggregation can be combined with preceding sustainable design principles such as DBOM contracts for utilities and transport infrastructure to provide further reduction in initial construction cost and ongoing operating costs.

The integration of technologies such as building utilities systems and sustainable transport equipment for commuters using hydrogen fuel cells has also been proven to simultaneously reduce household utilities and personal transport costs. The Honda Clarity vehicle for example is powered by hydrogen gas which is converted into electricity via an on-board fuel cell to drive electric motors with zero GHG emissions. An integrated "Home Energy Station" uses sunlight and building integrated photovoltaic (BIPV) panels to produce and store hydrogen for the Clarity vehicle from rain water with surplus hydrogen being used in a stationary fuel cell to produce low cost electricity and hot water for the home (AHMCI [33]). The UK Government [34] has recognised the strategic importance of hydrogen fuel for both stationary and motive power applications hence it has recently partnered with companies such as ITM Power and Shell to help accelerate the transition to zero emissions road transport by providing funding for increased deployment of urban hydrogen refuelling stations. Recognition of the fact that total building energy efficiency needs to be measured across both stationary and motive power metrics via leading green building codes such as Leadership in Energy and Environmental Design (LEED) supports the use of integrated technologies such as this Commuter Energy and Building Utilities System (CEBUS) (Weigel [35]). These integrated technologies can be combined with other proven sustainable design principles such as TOD strategies to provide further reduction in initial construction cost for new housing developments. Research by Rat [36] into the benefits of locating new housing estates close to public transport nodes using the TOD strategy has shown potential for reduced personal transport costs of up to $75 \%$. Studies conducted in major international cities including New York, London, Paris, Munich and Tokyo have demonstrated that public transport utilisation is positively correlated with increases in urban density. This study supports current international best practice of using higher density multi-resident housing schemes for the development / redevelopment of cities as a means of increasing public transport patronage 
(Wang [37]). By locating new developments near public transport nodes, developers are typically offered a reduction in car parking requirements per occupant, which in turn, provides for improved yield and a resultant reduction in the land cost per apartment City of Fremantle [38].

The AIA [39], Integrated Project Delivery (IPD) method provides the opportunity to design, build and operate new multi-resident housing facilities as cost-effectively as possible through formation of collaborative and productive teams from all sections of the design and construction supply chain. This integrated development approach also allows for local community attitudes and environmental conditions to be considered as part of the overall design optimisation process (Mani et al. [40]). At the same time, "lean" construction methods using value stream mapping (VSM) and process mapping (PM) techniques have been leveraged to support the IPD method by reducing design waste and delivering first capital cost savings of up to $18 \%$ (Goldstein and Rosenblum [41]). These combined methods were therefore suggested as the central control mechanism for integrating each of the preceding individual best practice sustainable design elements in order to provide a new ISD model as shown in the concept diagram in Fig. 1.

\section{RESEARCH METHODOLOGY DEVELOPMENT}

Following completion of the initial literature review and case studies, a paucity of local data on the CEBUS component of the proposed ISD model was noted hence further investigation was then undertaken as follows to develop a suitable research methodology so as to ensure coherence and complementarity between the smart, affordable and sustainable housing development problem facing the construction industry and the findings of previous research that support and inform use of the CEBUS method within the proposed ISD model (Fellows and Liu [42]):

- $\quad$ Context in which the proposed research will take place (Popper [43])

- Environmental variables that influence the research results (Baron and Kenny [44])

- The issue of objectivity (Drenth [45])

- Aristotle's inductive-deductive method (Losee [46])

- The current construction industry paradigm (Kuhn [47])

- Successful empirical research methods in construction (Remenyi et al. [48])

- Previous multi-resident housing industry research methods (Easthope et al. [49]).

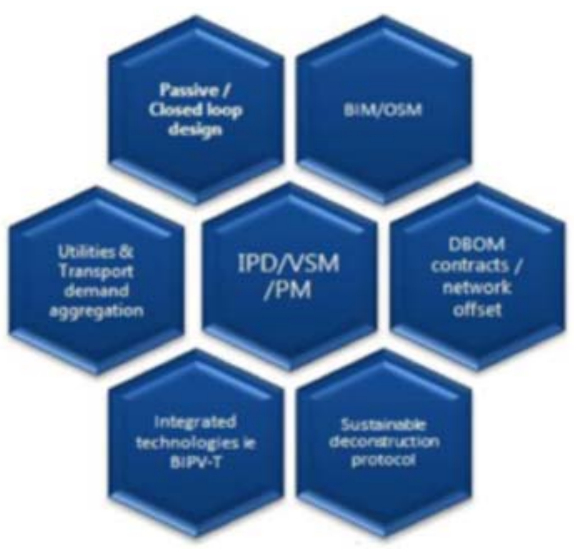

Figure 1: A new IS Design model. 


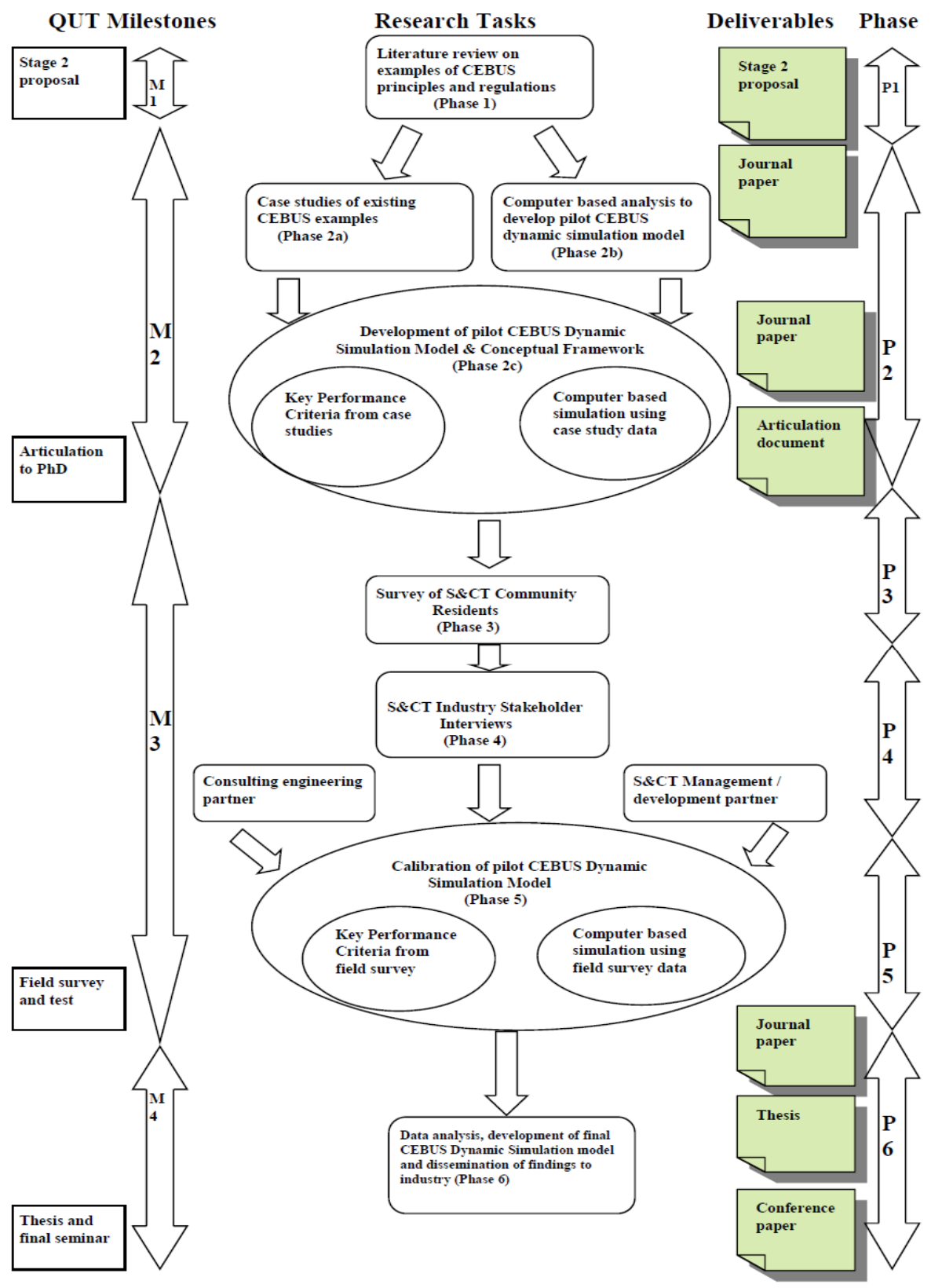

Figure 2: Overall research approach.

Based on this study of proven research methodologies for the construction industry and relevant research planning theory, the overall research approach was then formulated as shown in Fig. 2. 


\section{DECISION SUPPORT TOOL DEVELOPMENT THROUGH SURVEY AND TESTS}

Using the data provided from the preceding literature review and case studies that helped to inform development of the proposed ISD model, a spreadsheet simulation was then developed for a theoretical CEBUS with three possible renewable fuel/vehicle type variants - solar PV/battery electric vehicle (SolaDrive), biogas/compressed biogas vehicle (BioDrive) and hydrogen / fuel cell vehicle (HydroDrive) - which provided the engine for the pilot Decision Support Tool (DST). Mean data for the key input variables to the DST was then collected from the on-line survey of residents from a representative sample of the five hundred known multi-resident developments in the Brisbane urban and peri-urban areas which had been identified as being in mortgage stress and oil dependent by Dodson and Sipe [50] as well as having congested car parking at local public transport nodes (Translink [51]). This data was then combined with data from relevant local meteorology, vehicle manufacturer and banking web sites for entry into the pilot CEBUS DST to generate theoretical utilities and personal transport cost comparison graphs as shown in Figs 3-5.

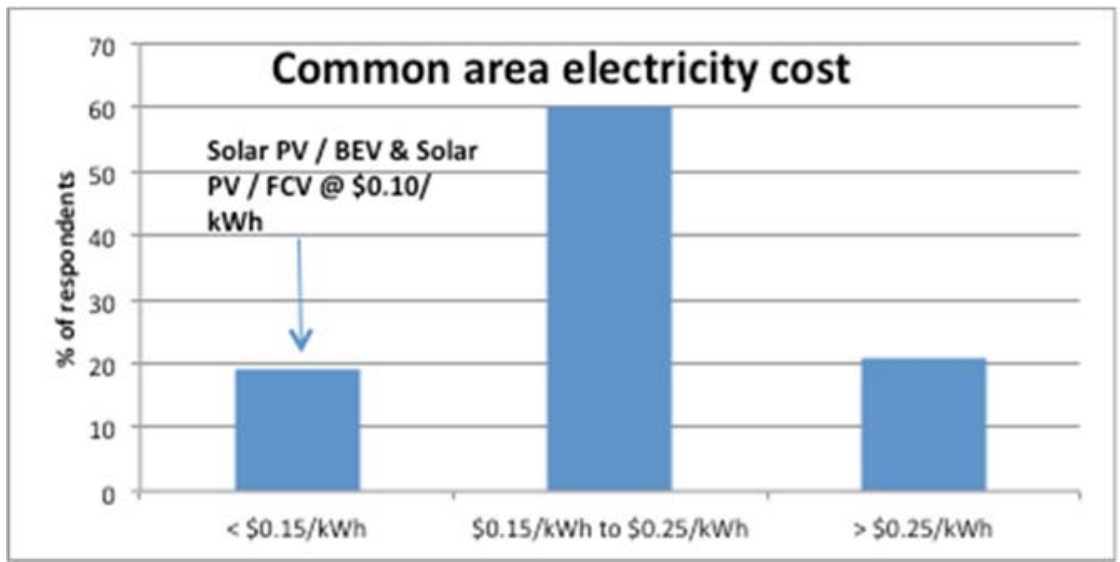

Figure 3: Common area electricity cost comparison.

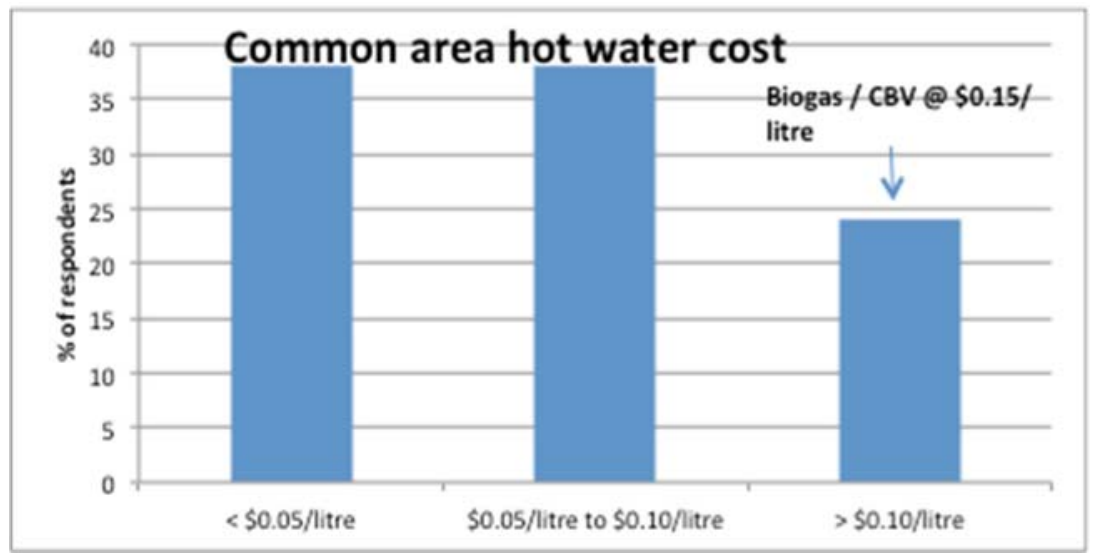

Figure 4: Common area hot water cost comparison. 


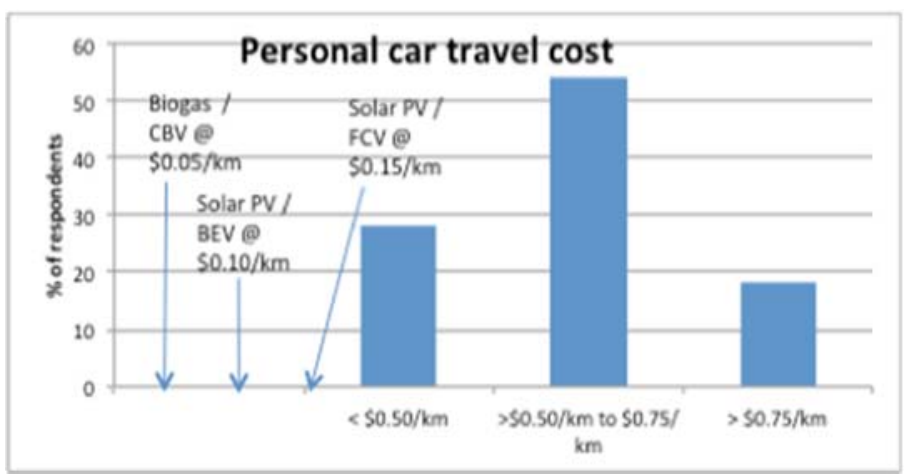

Figure 5: Personal transport cost comparison.

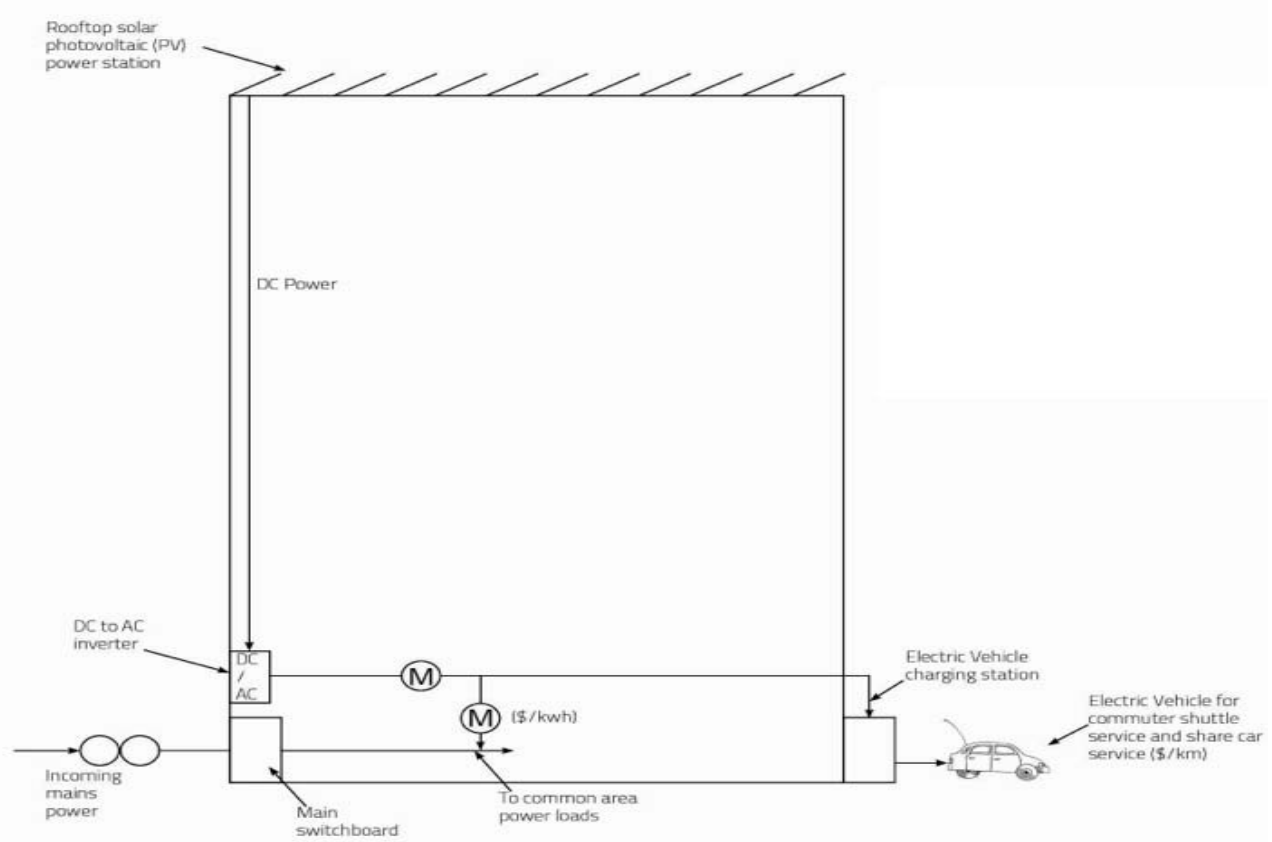

Figure 6: "SolaDrive" line diagram.

Given that these preliminary findings indicated that hot water costs are actually higher for the "BioDrive" CEBUS type and that no fuel cell vehicles were commercially available in Australia at the time, it was decided that the multi-resident housing pilot site will utilise the "SolaDrive" CEBUS type only as shown in Fig. 6.

A review of the estimated 500 multi-resident housing complexes in the Brisbane urban and peri-urban areas located near congested Translink park and ride stations and in postcodes previously identified as being in mortgage stress and oil dependent was then conducted in conjunction with various solar PV industry partners so as to cross-reference with existing 
pockets of solar PV installations in multi-resident communities. As a result of this exercise, a cluster of multi-resident housing communities with existing solar PV installations was found to exist in the suburb of Robina within a $5 \mathrm{~km}$ radius of the train station. Further investigation was then conducted at street level by driving past a number of multi-resident community sites in order to verify street addresses and resident manager contact details which resulted in the initial selection of "The Pavilions" scheme as shown in Fig. 7.

The Mitsubishi Outlander plug-in hybrid electric vehicle (PHEV) as shown in Fig. 7 was selected for use at The Pavilions multi-resident community site in order to assist with calibration of the pilot CEBUS "SolaDrive" DST. For the test period, this vehicle was allocated a dedicated parking space outside the community centre together with access to a ten (10) amp general purpose outlet (GPO) for charging. The next step of the multi-resident community pilot site test involved measurement of the typical solar insolation available throughout the day at the pilot site for operating a solar PV power system to charge the PHEV vehicle using an insolation meter from which a data file was then downloaded in order to develop a typical daily insolation graph. The data from this daily insolation graph was then combined with the typical solar PV conversion efficiency data together with the maximum available north facing roof area of $150 \mathrm{~m}^{2}$ on the community centre for a nominal $20 \mathrm{~kW}$ peak solar PV system in order to create a typical daily power output curve from the solar PV system.

The next step of the test procedure involved operation of the Mitsubishi Outlander PHEV at the test site in both "pool" and "share" modes throughout a typical operating day in order to record the vehicle charging profile and drive battery state of charge (SOC) for comparison with the available solar PV system output and the vehicle range requirements when operating in pure electric drive mode. A data logger unit was installed in-line with the vehicle's charging cable so as to enable total $\mathrm{kWh}$ of electricity used for charging and peak charging $\mathrm{kW}$ electrical demand to be recorded throughout the day for subsequent graphing. The road test began with a trial run from the Pavilions test site to the local train station at Robina and back again in order to simulate the vehicle operating in "pool" mode with four (4) passengers and the resident manager driving for drop-off in the morning and pick-up in the afternoon. The next stage of the test involved a trial run from the Pavilions test site to the local shopping centre at Robina and back again in order to simulate the vehicle operating in "share" mode with one (1) resident driver only.

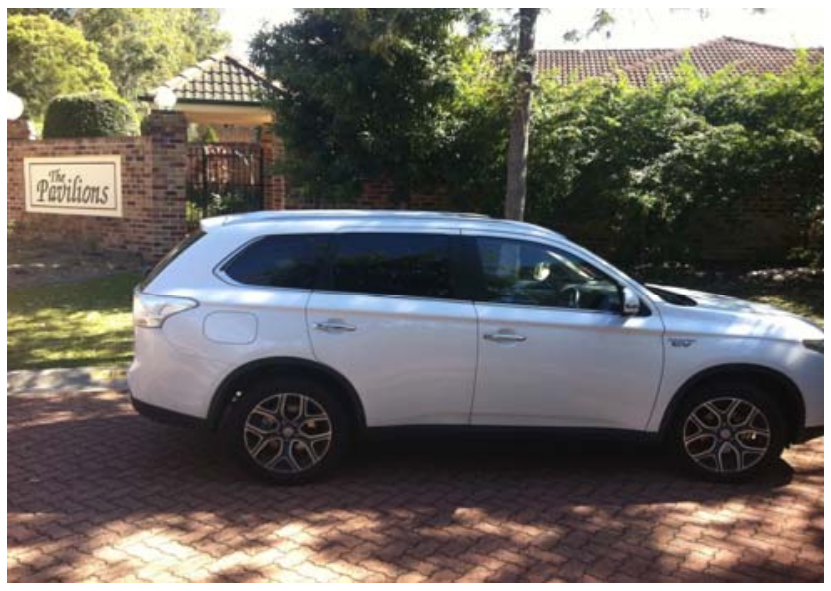

Figure 7: The Pavilions with Mitsubishi Outlander PHEV. 
The preceding data sets for each mode were then averaged as shown in Table 1.

It was noted that in no test run did the Mitsubishi Outlander PHEV return averaged "all electric" fuel consumption figures above the official green car guide figure of $0.134 \mathrm{kWh} / \mathrm{km}$ hence it was resolved that this "worst case" figure would be utilised in the updated SolaDrive DST. Whilst this figure is above that quoted for full BEVs it was considered prudent to use the higher PHEV figure so that DST output results remain conservative and realistic when compared with real world conditions. The next step of the trial involved data logging of the vehicle's input electrical energy $(\mathrm{kWh})$ and maximum electrical demand $(\mathrm{kW})$ so as to build up a typical daily load profile of the vehicle's charging events given the preceding typical daily "pool" and "share" operational modes. This data was then combined with the preceding operational test data sets in order to build up a typical daily charging profile which was then integrated with the preceding power output curve for the maximum $20 \mathrm{~kW}$ solar PV system output in order to compare projected PHEV charging times with the energy available from the solar PV system as shown in Fig. 8 which illustrates the fact that the proposed operation of the PHEV in both "pool" and "share" modes produces a charging profile that is well matched to the output capacity and profile of this system.

Table 1: Summary data from Mitsubishi Outlander PHEV road tests.

\begin{tabular}{|c|c|c|c|}
\hline $\begin{array}{c}\text { Road test } \\
\text { segment }\end{array}$ & $\begin{array}{c}\text { Elapsed time } \\
\text { (minutes) }\end{array}$ & $\begin{array}{c}\text { Total distance } \\
\text { (km) }\end{array}$ & $\begin{array}{c}\text { Average fuel } \\
\text { consumption } \\
\text { (kWh/km) }\end{array}$ \\
\hline $\begin{array}{c}\text { Pavilions to train } \\
\text { station }\end{array}$ & 9 & 6 & 0.078 \\
\hline $\begin{array}{c}\text { Train station to } \\
\text { Pavilions }\end{array}$ & 10 & 4 & 0.177 \\
\hline $\begin{array}{c}\text { Pavilions to } \\
\text { shopping centre }\end{array}$ & 10 & 6 & 0.139 \\
\hline $\begin{array}{c}\text { Shopping centre } \\
\text { to Pavilions }\end{array}$ & 8 & 5 & 0.1275 \\
\hline $\begin{array}{c}\text { "Pool" mode } \\
\text { average }\end{array}$ & 9.5 & 6 & 0.0745 \\
\hline $\begin{array}{c}\text { "Share" mode } \\
\text { average }\end{array}$ & 9 & 6 & \\
\hline
\end{tabular}

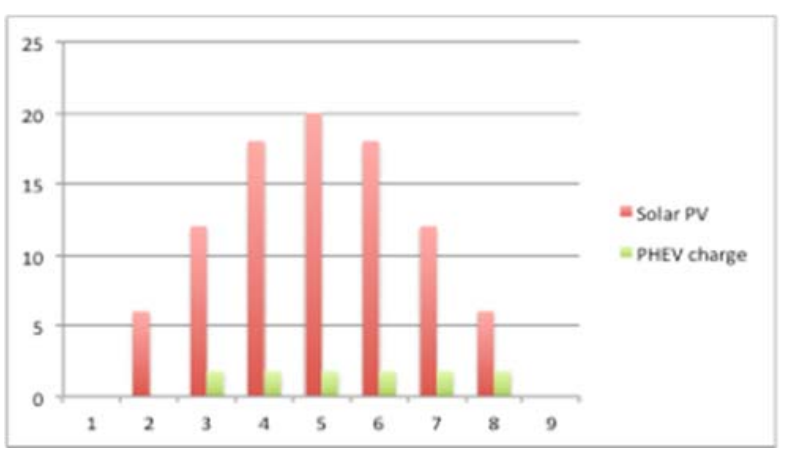

Figure 8: Mitsubishi Outlander PHEV daily charging profile versus solar PV output. 
The significance of the CEBUS "SolaDrive" method in terms of its potential contribution to the development of smart, affordable and sustainable multi-resident housing was then tested against average Australian wages, electricity usage/costs/carbon emissions and personal transport usage/costs/carbon emissions. Initial data from Strata Communities Australia (SCA) indicates that approximately 5,000,000 Australians live in 270,000 multiresident housing developments (SCA [52]). By combining this data with the average potential solar PV system size of $17.5 \mathrm{~kW}$ peak derived from the preceding survey of multi-resident housing schemes, this equates to a total annual solar PV electricity generation capacity of $6,480,000,000 \mathrm{kWh}$. The Australian Energy Council (AEC) has estimated that Australian households consume a total of $56,000,000,000 \mathrm{kWh}$ of electricity annually hence deployment of the "SolaDrive" method across all multi-resident community developments would contribute at least $11 \%$ towards this total consumption value (AEC [53]). Given that the average Australian home generates 12 tonnes of $\mathrm{CO}^{2} \mathrm{e}$ per annum from electricity consumption and that each $\mathrm{kWh}$ of coal based electricity generates $0.82 \mathrm{~kg}$ of $\mathrm{CO}^{2} \mathrm{e}$, this "SolaDrive" deployment also represents a reduction of at least 5 million tonnes of $\mathrm{CO}^{2} \mathrm{e}$ per annum (EPA Victoria [54].) The preceding survey of multi-resident housing schemes also indicated a potential solar PV generated electricity cost of $\$ 0.10 / \mathrm{kWh}$ compared with a mean survey cost of grid electricity at $\$ 0.20 / \mathrm{kWh}$ hence this represents a potential annual electricity cost saving of at least $\$ 405$ per multi-resident household or $\$ 162$ per capita. With regards to personal transport impact, data from the Australian Bureau of Statistics (ABS) indicates that the average multi-resident community inhabitant travels $26.8 \mathrm{~km}$ per day on weekdays each year (ABS [55].) By combining this data with the average potential "SolaDrive" share/pool car usage rate of $10 \%$ as derived from the preceding survey of multi-resident housing schemes, this equates to a total annual fossil fuel vehicle travel offset of 3,484 million kilometres. Given that the average Australian home generates 6 tonnes of $\mathrm{CO} 2 \mathrm{e}$ per annum from personal transport activities and that each $\mathrm{km}$ of fossil fuel based transport generates $0.256 \mathrm{~kg}$ of CO2e, this "SolaDrive" deployment also represents a reduction of at least 890 million tonnes of CO2e per annum (EPA Victoria [54]). The preceding survey of multiresident housing schemes also indicated a potential "pool" transport cost of $\$ 0.10 / \mathrm{km}$ compared with a mean survey cost of fossil fuel transport at $\$ 0.625 / \mathrm{km}$ hence this represents a potential annual personal transport cost saving of at least $\$ 3658$ per capita within participating multi-resident households. The total annual electricity and personal transport cost savings offered by the "SolaDrive" deployment therefore equate to $\$ 3,820$ per capita or approximately $6.5 \%$ of the average annual Australian wage.

\section{CONCLUSIONS}

The potential economic benefits offered via implementation of the CEBUS "SolaDrive" variant include $6.5 \%$ savings in annual wage expenses together with environmental benefits such as a $14 \%$ reduction in national annual GHG emissions from personal transport activities and household electricity consumption. This data also supports the hypothesis that significant social benefits can be simultaneously derived such as the reduction of mortgage stress for essential services workers via these significant annual electricity and transport cost savings together with reduction in road rage incidents given that up to seven (7) private cars can be taken off the road for each "SolaDrive" vehicle being operated in either "pool" or "share" mode. It should be noted that these initial results are limited to the Australian context only given that the DST data inputs have been derived from local electricity and personal transport usage/costs/carbon emissions metrics hence the DST will need to be modified for use in other jurisdictions such as the European Union. Further local research is proposed into the potential benefits of the CEBUS "HydroDrive" variant given that both Toyota and Hyundai have 
recently committed to commercial launch of their hydrogen fuel cell vehicles in Australia hence this research will form the basis of a future journal paper and joint industry case studies.

\section{REFERENCES}

[1] Mulliner, E. \& Maliene, V., Austerity and reform to affordable housing policy. Journal of Housing and the Built Environment, 28(2), pp. 397-407, 2013.

[2] Pollack, C., Griffin, B. \& Lynch, J., Housing affordability and health among homeowners and renters. American Journal of Preventative Medicine, 39(6), pp. 515$521,2010$.

[3] Sperandelli, D., Dupas, F. \& Dias Pons, N., Dynamics of Urban Sprawl, Vacant Land, and Green Spaces on the Metropolitan Fringe of São Paulo, Brazil. Journal of Urban Planning and Development, 139(4), pp. 274-279, 2013.

[4] Prickett, L. \& Bicknell, J., LID, LEED and Alternative Rating Systems - Integrating Low Impact Development Techniques with Green Building Design. Proc. of International Low Impact Development Conference, 2010.

[5] Yung, E., Chan, E. \& Xu, Y., Community-Initiated Adaptive Reuse of Historic Buildings and Sustainable Development in the Inner City of Shanghai. Journal of Urban Planning and Development, 140(3), 2013.

[6] HIA, Online. https://hia.com.au/ /media/HIA\%20Website/Files/IndustryBusiness/ Economic/publications/Extract_AffordMar\%2017.ashx.

[7] Zhao, J. \& Deng, W., Relationship of Walk Access Distance to Rapid Rail Transit Stations with Personal Characteristics and Station Context. Journal of Urban Planning and Development, 139(4), pp. 311-321, 2013.

[8] Norman, J., MacLean, H. \& Kennedy, C., Comparing High and Low Residential Density: Life-Cycle Analysis of Energy Use and Greenhouse Gas Emissions. Journal of Urban Planning and Development, 132(1), pp. 10-21, 2006.

[9] Habitat, Online. http://www.habitat.org/how/default.aspx.

[10] Gipton, S., Sustainable transport - are we there yet? Greenfleet News, 1 (1), 2009.

[11] Chen, D. \& Wen, Y., Effects of Freeway Mileage-Based Toll Scheme on the ShortRange Driver's Route Choice Behaviour. Journal of Urban Planning and Development, 2013.

[12] Pitt, M., Tucker, M., Riley, M.\& Longden, J., Towards sustainable construction: promotion and best practices. Construction Innovation: Information, Process, Management, 9(2), pp. 201-224, 2009.

[13] Delucchi, M. \& Kurani, K., How to Have Sustainable Transportation without Making People Drive Less or Give Up Suburban Living. Journal of Urban Planning and Development, 140(4), p. 04014008, 2013.

[14] Chaturvedi, S., Energy Efficiency and Sustainablility In Buildings. Proc. of AEI 2008: Building Integration Solutions, 2008.

[15] Miller, W., Kelvin Grove Urban Village Post-Occupancy Energy Use Survey, Queensland Sustainable Energy Industry Development Group (QSEIDG), Queensland University of Technology, 2007.

[16] Triantis, E., Tzouvadakis, J., Bougiatioti, F., Diamantidou, D. \& Chryssicopoulos, D., Urban Microclimate Investigation of Major Squares in Athens. Journal of Urban Planning and Development, 5(8), 2011.

[17] Codoban, N. \& Kennedy, C.A., Metabolism of Neighbourhoods. Journal of Urban Planning and Development, 2008.

[18] Reidy, P.C., Integrating Rainwater Harvesting and Stormwater Management Infrastructure: Double Benefit - Single Cost. Proc. of International Low Impact Development Conference, 2008. 
[19] Bailey, P. \& Brodkin, D., The Virtual Building. The Arup Journal, 42(2), p. 10, 2008.

[20] Issa, M.H., Rankin, J.H. \& Christian, A.J., Sustainability, Whole Life Costs, and Information and Communication Technologies: A Review of Published Works. Computing in Engineering, pp. 478-485, 2007.

[21] Wang, Y., Deng, X., Marcucci, D. \& Le, Y., Sustainable Development Planning of Protected Areas near Cities: Case Study in China. Journal of Urban Planning and Development, 139(2), pp. 133-143, 2013.

[22] Barnes, S., BIM-enabled Integrated Optimisation Tool for LEED Decisions. Computing in Civil Engineering, 2009.

[23] Forsspac, Online. http://www.forsspacglobal.com/wp-content/uploads/2016/12/3DServices.pdf.

[24] Meiling, J., Backlund, F. \& Johnsson, H., Managing for continuous improvement in off-site construction: Evaluation of lean management principles. Engineering, Construction and Architectural Management, 19(2), pp. 141-158, 2012.

[25] Sauer, M., Incentives for Green Residential Construction. Proc. of Construction Research Congress, 2009.

[26] Dahl, P., Horman, M., Pohlman, T. \& Pulaski, M., Evaluating Design-Build-OperateMaintain Delivery as a Tool for Sustainability. Proc. of Construction Research Congress, 2005.

[27] Warnken, J., Exploring the regulatory framework and governance of decentralised water management systems: a strata and community title perspective, New Water Commission, 2009.

[28] Kuhlen, A., Online. http://eprints.qut.edu.au/71841/1/148.pdf.

[29] Casey, T., Online. http://cleantechnica.com/2014/02/10.

[30] Tucker, L., Banking on Community Spirit, Bendigo Bank, 2004.

[31] Lin, Q., Huang, G., Huang, Y. \& Zhang, X., Inexact Community-Scale Energy Systems Planning Model. Journal of Urban Planning and Development, 136(3), pp. 195-207, 2010.

[32] The Waterfront, Online. http://www.thewaterfront.com.au/.

[33] AHMCI, Online. http://automobiles.honda.com/fcx-clarity/home-energy-station.aspx.

[34] UK Government, Online. https://www.gov.uk/government/news/23-million-boostfor-hydrogen-powered-vehicles-and-infrastructure.

[35] Weigel, B., Estimation of Potential Transportation and Building Energy Performance of Commercial Office Site Alternatives. Journal of Urban Planning and Development, 141(1), 2015.

[36] Rat, H., Better Mobility for People Worldwide. Proc. of Urban Public Transport, 2002.

[37] Wang, Z.W., Urban Development with Sustainable Public Transit Services. Proc. of AATT, 2006.

[38] City of Fremantle, Online. http://www.fremantle.wa.gov.au/one-planet/zero-carbon.

[39] AIA, Online.http://info.aia.org/SiteObjects/files/IPD_Guide_2007.pdf.

[40] Mani, M., Varghese, K. \& Ganesh, L., Integrated Model Framework to Simulate Sustainability of Human Settlements. Journal of Urban Planning and Development, 131(3), pp. 147-158, 2005.

[41] Goldstein, J. \& Rosenblum, J., The Costs and Benefits of Green Affordable Housing: Opportunities for Action, Green CDCs Initiative, Tellus Institute, Massachusetts, 2003. 
[42] Fellows, R. \& Liu, A., Research Methods for Construction, Blackwell Publishing Limited, 2008.

[43] Popper, K.R., Conjectures and Refutations: The Growth of Scientific Knowledge, Routledge: London, 1989.

[44] Baron, R.M. \& Kenny, D.A., The moderator-mediator variable distinction in social psychological research: conceptual, strategic and statistical considerations. Journal of Personality and Social Psychology, 51(6), p. 1173, 1986.

[45] Drenth, P.J.D., Research in work and organizational psychology: principles and methods. Handbook of Work and Organizational Psychology, 1(2), 1998.

[46] Losee, J., A Historical Introduction to the Philosophy of Science, 3rd ed., Opus: Oxford, 1993.

[47] Kuhn, T.S., The Structure of Scientific Revolutions, 3rd ed., The University of Chicago Press: Chicago, 1996.

[48] Remenyi, D., Williams, B., Money, A. \& Swartz, E., Doing Research in Business and Management, An introduction to Process and Method, Sage: London, 1998.

[49] Easthope, H., Randolp, B. \& Judd, S., Managing Major Repairs in Residential Strata Developments in New South Wales, The University of New South Wales, 2009.

[50] Dodson, J. \& Sipe, N., Unsettling Suburbia: The New Landscape of Oil and Mortgage Vulnerability in Australian Cities, Urban Research Program Research Paper 8, Griffith University, 2008.

[51] Translink, Online. https://publications.qld.gov.au/dataset/annual-report-2015-2016transport-and-main-roads.

[52] SCA, Online. https://www.strata.community/.

[53] AEC, Online. https://www.energycouncil.com.au/.

[54] EPA Victoria, Online. http://www.epa.vic.gov.au/.

[55] ABS, Online. http://www.abs.gov.au/. 